\title{
Protein RRP5 Homolog
}

National Cancer Institute

\section{Source}

National Cancer Institute. Protein RRP5 Homolog. NCI Thesaurus. Code C106427.

Protein RRP5 homolog (1871 aa, 209 kDa) is encoded by the human PDCD11 gene.

This protein is involved in rRNA biosynthesis. 